\title{
Abstracts of Articles
}

\section{"Vietnamese Ceramic Trade to the Philippines in the Seventeenth Century" by KERRY NGUYEN-LONG}

The trade in ceramics from northern Vietnam into island Southeast Asia in the third quarter of the seventeenth century is examined using historical and literary accounts, and excavations in Vietnam and elsewhere. A credible typology is presented to demonstrate that, contrary to perceptions common in ceramic literature, these ceramics could have been traded into the Philippines during this period.

"Military Mortality in Tropical Asia: British Troops in Tenasserim, 1827-36" by PETER COCLANIS

The author compiles and analyzes mortality data relating to British troops in the Tenasserim provinces of southern Burma during the $1820 \mathrm{~s}$ and $1830 \mathrm{~s}$, and compares these data with mortality figures for British troops in other parts of the tropical world during the same period. The comparison demonstrates that mortality levels in Tenasserim were relatively low compared to levels reached in some other parts of the tropics, particularly in West Africa and the West Indies.

\section{"Imagining Selves and Inventing Festival Sriwijaya" by TIMOTHY P. DANIELS}

South Sumatran political elites have recently invented a regional festival which embeds images constitutive of a dominant identity construct. Festival practice and discourse project provincial identity as Malay and situate it as a component of Indonesian nationality. This redefinition of Malayness is being contested by alternative modes of self-definition in Palembang.

\section{"The Colonial Heritage of Human Rights in Indonesia: The Case of the Vote for Women, 1916-41" by ELSBETH LOCHER-SCHOLTEN}

This article argues that the human rights tradition in Indonesia has colonial as well as Indonesian roots, while universalist claims of Western human rights activists date from the post-colonial period. The point is demonstrated by analyzing one case of human rights: the struggle for the female vote for city councils, which was won in 1941. The Dutch colonial government was slow to recognize voting rights for European women, but even slower to do so with regard to women from Indonesian and "Foreign Oriental" (Chinese and Arab) population groups. Arguments based on "Asian values", such as adat (traditional law) and Islam, were used to legitimize this reluctance. 
"The Visible Hand in Tempo Doeloe: The Culture of Management and the Organization of Business in Java's Colonial Sugar Industry" by ROGER KNIGHT

In the middle of the nineteenth century, technological and organizational changes in the Java sugar industry - delineated here in terms of a "colonization" of the sugar factory — began to set the industry apart from the dominant socio-cultural environment in which it was situated. These developments helped the sugar industry survive a period of severe crisis in the mid-1880s and resume a vigorous expansion by the end of the century.

\section{“"Iron Claws on Malaya': The Historiography of the Malayan Emergency" by KARL HACK}

Authors such as Anthony Short and Richard Stubbs have suggested that the Emergency was at a stalemate in 1951, and that "hearts and minds" measures or the leadership of Sir Gerald Templer subsequently transformed the British campaign. By contrast, this article argues that the Emergency reached a critical point as early as 1951-52, and that Britain's success was based less on the wooing of "hearts and minds" than on "screwing down" Communist supporters through population control measures, an approach which proved effective because of local ethnic, social and political patterns.

\section{"Japan through Vietnamese Eyes (1905-1945)" by TRAN MY-VAN}

During two significant periods in Vietnamese history, 1905-1910 and 1940-45, Japan played a considerable part in shaping political and social developments within Vietnam. This study of the Vietnamese nationalist encounter with the Japanese examines the complex interaction between the two countries, and describes the impact of this relationship on Vietnam's efforts to achieve independence immediately after World War Two. 